\title{
High-resolution seismic imaging of Paleozoic rocks in the Mora area, Siljan Ring structure, central Sweden
}

\author{
Harbe Muhamad $^{\text {ab }}$, Christopher Juhlin ${ }^{\text {a }}$, Daniel Sopher ${ }^{a}$, Oliver Lehnert ${ }^{\text {c d e f }}$, Arzu Arslan ${ }^{\mathrm{g}} \&$ Guido Meinhold \\ ${ }^{a}$ Department of Earth Sciences, Uppsala University, Villavägen 16, SE-752 36 Uppsala, Sweden; \\ harbe.muhamad@geo.uu.se \\ ${ }^{b}$ Department of Geology, Salahaddin University, Erbil, Kurdistan Region, Iraq \\ ${ }^{c}$ Key Laboratory of Economic Stratigraphy and Palaeogeography, Nanjing Institute of Geology and \\ Palaeontology, Chinese Academy of Sciences, 39 East Beijing Road, Nanjing 210008, China \\ ${ }^{d}$ GeoZentrum Nordbayern, Abteilung Krustendynamik, Friedrich-Alexander University of Erlangen-Nürnberg, \\ Schlossgarten 5, D-91054, Erlangen, Germany \\ ${ }^{e}$ Institute of Geology at Tallinn University of Technology, Ehitajate tee 5, 19086 Tallinn, Estonia. \\ ${ }^{f}$ Faculty of Environmental Sciences, Czech University of Life Sciences Prague, Kamýcká 129, 16521 Praha 6 - \\ Suchdol, Czech Republic \\ ${ }^{g}$ Ulmenweg 2, D-37077, Göttingen, Germany \\ ${ }^{h}$ Geowissenschaftliches Zentrum der Universität Göttingen, Abteilung Sedimentologie / Umweltgeologie, \\ Goldschmidtstraße 3, D-37077 Göttingen, Germany
}

\begin{abstract}
The Late Devonian Siljan Ring structure in Sweden is the largest known impact structure in Europe. The present-day structure comprises a central dome that is about $20-30 \mathrm{~km}$ in diameter, which is surrounded by a ring-shaped depression. In this study, we focus on the southwestern part of the Siljan Ring with the aim to map the structure of the Paleozoic sedimentary rocks. Four 2D high-resolution seismic lines with a total length of about $3 \mathrm{~km}$ were acquired in the Mora area. A three component eighty-unit land streamer, combined with wireless recorders, was used for data acquisition along with a weight drop source. Processing of the data shows that clear reflections are present, but results are less distinct where external noise was present during acquisition or the maximum source-receiver offset was too short. Petrophysical measurements on core samples, core log data and a density model along one line were used to guide the interpretation of the seismic sections. These data


demonstrate that fault blocks are present in the study area and that the individual blocks have been affected differently by impact-related tectonics.

Keywords: Siljan Ring impact structure, Paleozoic rocks, Mora, seismic reflection

\section{Introduction}

The Late Devonian Siljan Ring structure in Sweden is the largest known impact structure in Europe (Fig. 1). It comprises a central uplift that is about $20-30 \mathrm{~km}$ in diameter surrounded by a ring-shaped depression (Juhlin \& Pedersen 1987). In the early 1980s, the structure attracted the interest of the Swedish State Power Board (Vattenfall) as a potential reservoir for abiogenic gas (Donofrio et al. 1984; Boden \& Eriksson 1988), and several seismic reflection profiles were acquired in the Siljan Ring area, especially in the central to northern parts and in the eastern part. In addition, two deep wells were drilled, the Gravberg-1 well (about $6.8 \mathrm{~km}$ deep) in the northern part and the Stenberg-1 well (about $6.5 \mathrm{~km} \mathrm{deep)} \mathrm{in}$ the central part. Results from these studies showed that felsic rocks are generally seismically transparent and that high amplitude sub-horizontal reflections represent thin $(5-50 \mathrm{~m})$ dolerite sills within the felsic rocks (Juhlin 1990; Papasikas \& Juhlin 1997).

In 2011, two seismic profiles (at Mora and Orsa) were acquired in the western part of the Siljan Ring (Juhlin et al. 2012; Fig. 1). The Mora profile, $10 \mathrm{~km}$ long and striking NW-SE, and the Orsa profile, $12 \mathrm{~km}$ long and striking NE-SW, were geared to map the Paleozoic successions in order to locate potential future scientific well sites that would allow penetration of the sedimentary successions and the basement rocks below. Results from these investigations show a complex and discontinuous reflection pattern with significant faulting, especially along the Mora profile (Juhlin at el. 2012). The Mora profile was interpreted to have 
an approximately $200 \mathrm{~m}$ thick section of Silurian rocks overlaying a structurally thickened succession of Ordovician strata (maximum thicknesses of about $400 \mathrm{~m}$ ). Increased thicknesses caused by impact tectonics were interpreted to be generally less along the Orsa profile (Juhlin at el. 2012).

Recently, Igrene AB (a Swedish company focusing on hydrocarbon exploration) drilled several wells in the southern half of the Siljan Ring for the purposes of gas exploration (e.g. Mora 001 to c. $448 \mathrm{~m}$ depth, Solberga 1 to c. $280 \mathrm{~m}$ depth, and Stumsnäs 1 to c. $545 \mathrm{~m}$ depth; Fig. 1). Analysis of the Mora 001 core shows an unconformity between the top of the Middle Ordovician carbonate rocks and the Lower Silurian clastic rocks, interpreted to be due to the passage of a Caledonian peripheral forebulge during tectonic loading of thrust sheets to the west (Lehnert et al. 2012). The Stumsnäs 1 core is structurally complex and contains a slab of basement rock that overlies the Paleozoic successions (Arslan et al. 2013; Lehnert et al. 2013).

Four of the Igrene $A B$ wells in the Mora area were geophysically logged (Muhamad et al. 2015). Sonic velocity, temperature and electrical sondes were used for logging, and the data were compared to the lithology of the Mora 001 core. The logging data showed large differences in the log response between some of the wells, suggesting a complex structure in this area (Muhamad et al. 2015). The Mora 001 sonic log was used to generate a synthetic seismogram which showed that, at least in this area, the boundary between Silurian clastic rocks and Ordovician limestone produces a strong seismic reflection (Muhamad et al. 2015).

In this study, we focus on the southwestern part of the impact structure with the main objective to map the Paleozoic successions and structure and to determine which faults might be present in the Mora area. We base the interpretation on four new reflection seismic profiles 
that were acquired in an industrial area south of Mora (Fig. 2). In order to help calibrate the seismic data we used petrophysical data measurements on the Mora VM-2 core samples to generate a synthetic seismogram to tie with the seismic data (well location shown in Fig. 2). Additionally, ground gravity data were acquired along one of the profiles and 2.5D density forward modeling was performed to help further constrain the seismic interpretation. Our interpretation shows that the Paleozoic successions change character rapidly across the study area. We attribute these changes to impact tectonics.

\section{Geological setting}

The study area is located in the southwestern part of the Siljan Ring impact structure (Fig. 1). The ring itself is outlined by a circular shaped depression formed by a Late Devonian meteorite impact (380.9 $\pm 4.6 \mathrm{Ma}$, Jourdan et al. 2012). The Siljan Ring impact structure is located on the boundary between two geological units, the Svecofennian Domain (c. $1.9 \mathrm{Ga}$ ) and the Transscandinavian Igneous Belt (TIB; 1.64-1.74 Ga; Collini 1988). The Precambrian rocks (Siljan granite and Järna granite) in the study area belong to the TIB.

Figure 1 shows a geological map of the study area and illustrates how Lower Paleozoic successions have been preserved from later erosion by down-faulting in the post-impact circular depression (Kresten et al. 1992). Outcrops in the Siljan Ring are few and mainly concentrated in its northern, central and eastern parts. At these outcrops significant deformation can be observed, where the Paleozoic strata are often steeply inclined or overturned. 
The following text in this section describes the Igrene $A B$ drill cores from the Mora area, which are visually summarized in Figure 3 . As already mentioned, a previous study on drill cores from the Mora area (Lehnert et al. 2012) shows that there is a stratigraphic gap between the Middle Ordovician to the Lower Silurian. This is exemplified by about $224 \mathrm{~m}$ of Silurian strata overlying a thin Ordovician unit in the Mora 001 core (see Figs. 1 and 2 for location). Analysis of geophysical well data from the Mora area (Muhamad et al. 2015) shows that there are rapidly changing lithologies in this structurally complex area and that the tectonically induced thickness of the Ordovician rocks in the subsurface is up to approximately $300 \mathrm{~m}$, while the thickness of the Silurian succession is up to approximately $235 \mathrm{~m}$.

In the Mora 001 core (located close to Line 2 in this study; Fig. 2), the approximately $220 \mathrm{~m}$ thick Silurian succession consists mainly of shale/mudstone and marl which is assumed to be upper Llandovery through Wenlock in age (Lehnert et al. 2012). These lithologies are typical for the Silurian section in all of the wells drilled within the study area. Note that in the Mora 001 core there is an approximately $30 \mathrm{~m}$ thick sandstone interval at about $70 \mathrm{~m}$ depth that is underlain by an approximately $10 \mathrm{~m}$ thick siltstone interval. Below the Silurian in the Mora 001 well there is an approximately 20 m thick section of Lower to Middle Ordovician limestone (Lehnert et al. 2012). Unlike the other wells in the area, the Mora 001 well appears to represent a sequence largely unaffected by faulting and impact-related deformation, hence it is considered here to be representative of the pre-impact sequence in the area.

The Mora VM-2 well is also located along Line 2, approximately $500 \mathrm{~m}$ away from the Mora 001 well. Here the approximately $95 \mathrm{~m}$ thick Silurian section exhibits lithologies similar 
to the 'upper shale member' in the Silurian siliciclastic succession in the Mora 001 well. The thickness and character of the Ordovician strata differs significantly between the Mora VM-2 and Mora 001 wells. Unlike the Mora 001 well, the Ordovician strata in the VM-2 well appear to be intensely deformed. Several faults are observed in the Mora VM-2 well, most notably, the upper part of the Ordovician strata appears to be intersected by many faults. Furthermore, faults appear to mark the boundary between the Silurian and Ordovician strata in the well (Muhamad et al. 2015). Based on preliminary core analysis it is clear that the stratigraphic succession in this well is not continuous. It has been logged but will be described in detail in a separate publication. In this fault block, a lower continuous and autochthonous succession is observed. The continuous sequence at the base of the well consists of basement strata overlain by lower Ordovician shelf carbonates. Above this, a massive local mound succession is observed, which appears to be deformed. The mound succession may have formed along the forebulge during late Middle/early Late Ordovician times (Lehnert et al. 2012). This would infer that (despite being lithologically comparable) these mounds were formed earlier than the massive Boda mounds found in the north-central and eastern part of the ring structure.

The autochthonous lower succession in the Mora VM-2 well starts at $392.69 \mathrm{~m}$ with a 3 $\mathrm{cm}$ thin glauconitic sand cover on the basement overlain by the Latorp Limestone (Ebbestad \& Högström 2007) with an intercalation of Toyen Formation equivalents. Above this, the Lanna Formation and an interval which can be compared to the Täljsten interval is encountered. A fault at about $382.5 \mathrm{~m}$ marks the boundary between the Täljsten interval below and a succession of upper Lanna Limestone, Täljsten equivalents, Holen Limestone and a reddish to greenish limestone succession which based on lithologies may be coeval to the Segerstad, Skarlöv, Seby and Folkeslunda limestones (Ebbestad \& Högström 2007). It is not clear if the mainly grayish wackestone and packstones with many orthocerathids above 
entirely represent shallower equivalents to the Furudal and Dalby limestones, future $\delta^{13} \mathrm{C}$ analysis and conodont biostratigraphy may solve this problem. At $350 \mathrm{~m}$, analysis of the first conodont fauna recovered from this part of the succession indicates the Pygodus anserinus Biozone and, therefore, an uppermost Darriwilian to lower Sandbian age for this level which in turn would fit with the timing of Furudal deposition. After the sedimentation of a few meters of coarse-grained crinoidal wacke- to packstone, the first mound limestone is encountered at $343.93 \mathrm{~m}$ and ends at a fault at $223.89 \mathrm{~m}$. These autochthonous thick mound limestones with rare crinoids and abundant stromatactis are similar in lithology to the younger (uppermost Katian through Hirnantian) Boda mounds, but must, judging from their stratigraphic position, have formed much earlier, possibly parallel or close to the Middle/Upper Ordovician forebulge area discussed by Lehnert et al. (2012).

This lower succession in Mora VM-2 is separated by a fault zone from an upper succession of allochthonous, homogeneous and whitish (heated by the impact and originating from the impact site?) Boda Limestone with a predominantly sub-vertical bedding reflected by stylolithisation. This fault-bounded Boda Limestone $(223.89-95.71 \mathrm{~m})$ is in contact with the overlaying dark greenish Silurian shales and intersected by a number of faults. Impact-related fault zones, tectonic breccias and sediment injections are observed, as well as a dark bituminous cover on some fault planes. These fractured and shattered mound limestones have presumably been transported from the central part of the impact structure to this area in the outer and western part of the ring. Aside from the older massive mound deposition possibly close to the forebulge mentioned above, such massive mound limestones are not typically found in the western part of the Siljan Ring area. 
No geophysical logs are available for the Mora MV-3 well, located on Line 1 (Fig. 2). Preliminary inspection of the core data (based mainly on Igrene AB photographs of core boxes) demonstrates that the sequence is highly deformed, where the Ordovician-Silurian sequence is due to the development of a thick package of structurally repeated slices. Our preliminary assessment of the core lithologies indicates that the uppermost part of the succession, which starts underneath the Quaternary cover at $9.35 \mathrm{~m}$, consists predominantly of fine-grained Silurian siliciclastics. Greenish shales in the uppermost $60 \mathrm{~m}$ are in parts highly fractured and followed by a package of reddish and greenish shales, and comparable to those of the tricolor member in the Mora 001 core (Lehnert et al. 2012). Below these shales, impact-related faulting lead to numerous repetitions of the Ordovician and Silurian units. The contrast in the thicknesses of the Silurian and Ordovician successions between these wells and the presence of a large number of faults highlights the variability and complexity of the sedimentary sequence in this area.

The stratigraphy as represented by the Mora MV-3 core (Fig. 3) is unique in that even the lowermost part of the regular local Paleozoic sequence is highly affected by impact tectonics and that most of the Lower and Middle Ordovician predominantly carbonate units have been cut out by faulting in this fault block. The depths mentioned below are those indicated on the boxes from the photo documentation by Igrene $A B$. Fracture zones, mineralization and impact-related faulting occur already in the heterogeneous crystalline basement (dominated by granitic rocks with gabbroic intercalations), located between 434.90 and $351.40 \mathrm{~m}$. A $0.84 \mathrm{~m}$ thick coarse-grained conglomerate overlies the intensely fractured basement. It is followed by $2.5 \mathrm{~cm}$ marl and $1.27 \mathrm{~m}$ somewhat atypical Latorp Limestone (with greenish and yellowish nodules). This succession is in faulted contact with and juxtaposed to a succession of gray and reddish orthocerathid limestones, with many orthocerathids typical 
for the thin lithologic units above the Holen and Segerstad limestones. It may be equivalent to the Skarlöv, Seby and Folkeslunda limestones (Ebbestad \& Högström 2007). These rocks are separated by a fault at $350.1 \mathrm{~m}$ from deeper water marly limestones showing repeated internal faulting and which may partly be (?) an equivalent to the Furudal and Dalby limestone succession and possibly the Freberga Formation. Due to the significant faulting it is not evident which parts of the succession are preserved without biostratigraphic data. Above a fault at $329.5 \mathrm{~m}$, shaley limestones and nodular limestones with shale (equivalents to the Freberga Formation?) followed by denser nodular limestone (equivalents to the Slandrom Formation?) and deeper water shaley nodular limestones (upper Slandrom Formation?; from approximately 320.1 to $316.4 \mathrm{~m}$ ) are present. These are in sedimentary contact with the Fjäcka Shale, which at $311.7 \mathrm{~m}$ is separated by a fault from greenish shales with mudstones (equivalent to the Loka Formation?). These units, as well as the other Ordovician shale/mudstone units higher up, and their repeated layers presumably represent deeper water equivalents to the more lime-dominated units such as the Slandrom Limestone, Jonstorp and Loka formations to the east. Several repetitions of Fjäcka Shale, up to the highest slice situated between 159.4 and $152.1 \mathrm{~m}$, give some indications that a major part of the associated sediments are Upper Ordovician in age, as well as the up to $135.8 \mathrm{~m}$ overlaying Ordovician limestones. The whole Upper Ordovician part of the succession is repeated and thickened due to overturned to recumbent folding and probable subsequent thrusting. The deeper water equivalents to the Upper Ordovician limestone formations partly look like the shale/mudstone members in the Silurian succession in Mora 001, but the carbonate content seems to be much higher.

More than $67 \mathrm{~m}$ of Silurian siliciclastics, consisting of partly deformed and alternating greenish-grayish shale-mudstones and greenish shales, are intercalated between a probable 
thrust on top of a Fjäcka Shale at $258.7 \mathrm{~m}$ and the base of a $0.8 \mathrm{~m}$ thin thrust slice of Fjäcka Shale at $191.6 \mathrm{~m}$. This intercalation reflects internal folding and faulting of larger scale folds which can potentially be seen on the stacked seismic image from Line 1 (between CDP 500 and 350 at a depth between 100 and $300 \mathrm{~m}$ ) described later in the chapters on geophysical results. The exclusively Silurian and partly disturbed siliciclastic succession in the upper part of the core, juxtaposed by a fault to the underlying Upper Ordovician limestones (Jonstorp Formation) at $135.8 \mathrm{~m}$, is composed of a shale/mudstone member (135.8-98.5 m), some reddish/greenish shales (equivalents to the tricolor member in Mora 001?; 98.5-77.4 m) and dark greenish shales (77.4-9.35 m) underneath the Quaternary cover.

It is worth noting that the Jonstorp and Loka formations are repeated several times in probable thrust slices, but there are only two thin relicts of its competent equivalent, the Upper Ordovician Boda Limestone, within the different slices of the core (190.5 to $191.6 \mathrm{~m}$ in contact with shale nodular limestone of the Loka Formation; 146.8-147.2 m sedimentary intercalation in a gray/greenish Jonstorp Formation). This may indicate that this depositional area was deeper and more outboard than the shallower shelf areas with mound formation to the east and much deeper than the near-forebulge environments, and that only limited formation of mound limestone occurred in this setting.

Finally, it must be noted that the lithological interpretation of the Mora MV-3 core succession is based on the local experience of the authors while interpreting the photo set of the core boxes provided by Igrene $A B$. The lithological core succession must be investigated carefully on-site for drawing exact and detailed logs. 


\section{Seismic data acquisition}

During the summer of 2015, four seismic lines were acquired in the Mora area (Fig. 2). For the survey we used a seismic land streamer system along with 50 single component (1C) wireless units. The land streamer was a prototype three component MEMS- (micro-electro mechanical system) based seismic system that was developed by Uppsala University (Brodic et al. 2015). The system, in combination with wireless and cabled sensors, is useful for various applications, especially for noisy environments or areas where high resolution images of the subsurface are needed. The configuration used at Mora consisted of four segments of twenty sensors. Three segments contained twenty 3C-sensors with $2 \mathrm{~m}$ spacing, and the fourth consisted of twenty $3 \mathrm{C}$-sensors with $4 \mathrm{~m}$ spacing, giving a total streamer length of 200 $\mathrm{m}$. These segments were towed in series and synchronized with the 50 wireless sensors (1C). The spacing for the wireless units varied between 4 and $20 \mathrm{~m}$

We used a Bobcat drop hammer as seismic source and the land streamer and wireless units as receivers. The shot spacing was $4 \mathrm{~m}$ and at each position we recorded 5 hits. To increase the signal-to-noise ratio we stacked the shot records vertically. The sensor and wireless locations were surveyed using a DGPS (differential GPS) system, with high accuracy, particularly in open terrains (horizontally $\pm 0.5 \mathrm{~cm}$, vertically $\pm 1 \mathrm{~cm}$ ). Line 1 and Line 2 were directed in NE-SW and Line 3 and Line 4 in NW-SE (Fig. 2). Combined, the total length for the four lines was about $3 \mathrm{~km}$. The combination of the longer offsets from the wireless system and the close receiver spacing at shorter offsets from the land streamer was designed to provide images from the near surface down to the base of the Paleozoic succession. A summary of the main acquisition parameters is given in Table 1. 


\section{Seismic data processing}

Table 2 shows the main processing steps applied to the data. The processing was designed to reduce noise and to enhance any reflections masked by the noise. Only the vertical component of the land streamer data was used and these were merged with the $1 \mathrm{C}$ wireless data. Data quality varied along the profiles depending upon the near surface conditions, traffic influence and industrial noise. Straight stacking lines with a Common depth point (CDP) spacing of $2 \mathrm{~m}$ were used when applying the geometry. First breaks were generally of good quality along the profiles and these were first picked automatically and then manually inspected and corrected where needed. Furthermore, we used the first arrival picks to estimate refraction static corrections. Dead and noisy record traces were removed from the data.

Prior to stacking the data we applied some filtering to increase the signal-to-noise ratio, such as spectral equalization, Wiener deconvolution and band pass filtering. After stacking the data along the profiles they were migrated using a finite difference algorithm. Finally, we estimated velocity functions for each line to convert the migrated section to an approximate depth section. To determine the velocity model for depth conversion we used a combination of stacking velocities, well data and velocity information from the first arrivals in the pre-stack seismic data. For Lines 1, 2 and 3, laterally variable velocity models were specified, while on Line 4 a 1D velocity model was used.

\section{Petrophysical data and synthetic seismogram}


An important goal of seismic data interpretation is to map the subsurface geology, such as the depth to lithological units, the thicknesses of formations and to define subsurface structures. However, the seismic data consist of images of the subsurface and interpretation of geological structures generally requires wells or drill cores within or near the seismic survey area for comparison. A synthetic trace based on well logs is a simple method for calibrating the seismic data. Visual matching of the seismic data and the synthetic trace allows identification of key reflectors. To generate the synthetic seismogram, sonic and density logs from the selected well are required. If these are lacking, a synthetic seismogram may be generated based on the lithologies of the well and measurements on the core.

In the study area, five wells were drilled by Igrene $A B$ and four of these were geophysically logged by Muhamad et al. (2015). The Mora 001 and Vattumyra Production wells are close to each other (Fig. 2) and logged to approximately $356 \mathrm{~m}$ and $420 \mathrm{~m}$, respectively. The synthetic seismogram from the Mora 001 well generated by Muhamad et al. (2015) is used in this study to tie with seismic Line 2. The Mora MV-3 well was drilled to approximately $440 \mathrm{~m}$ depth, but was not logged. The core boxes, however, were inspected and a preliminary documentation was made as described above.

Since no geophysical sonic and density logs were available for the Mora VM-2 well we used P-wave velocity and density measurements from the core samples to generate blocked pseudo-velocity and density logs. The velocity function was converted to a time function with a $1 \mathrm{~ms}$ sampling interval (Fig. 4). Furthermore, the acoustic impedance and the reflection coefficient of the Mora VM-2 well lithologies were calculated. For generating the synthetic 
trace we used a Ricker wavelet as a source function with a dominant frequency of $125 \mathrm{~Hz}$ (Fig. 4).

Figure 4 shows that the highest amplitude reflection is generated between the Silurian and Ordovician rocks at about $0.043 \mathrm{~s}$. A large increase in velocity occurs at the depth of 95 m on the velocity log. Muhamad et al. (2015) also concluded that the boundary between the Silurian and Ordovician successions in the Mora 001 well was expected to generate the highest amplitude reflection in the area. Furthermore, the boundary between the felsic and mafic rocks is expected to generate a relatively strong reflection at $0.171 \mathrm{~s}$, corresponding to a depth of $480 \mathrm{~m}$ (Fig. 4). The boundary between the Ordovician and felsic basement rocks is anticipated to generate only a very low amplitude reflection at vertical incidence in this area.

\section{Gravity data acquisition, processing, and modeling}

Gravity data were acquired in 2013 along Line 2 (13 points) using a Lacoste-Romberg G-786 gravimeter with a station spacing of about 100-150 m (Fig. 2). The gravity points were surveyed by an MK3-Chameleon differential GPS (DGPS) instrument with a high accuracy, particularly in open terrains (horizontally $\pm 0.5 \mathrm{~cm}$, vertically $\pm 1 \mathrm{~cm}$ ). A base station was established along the line and was surveyed at the beginning and end of the gravity survey. We applied the standard corrections to the gravity measurements. The Bouguer anomaly was calculated using a uniform reference density of $2.67 \mathrm{~g} / \mathrm{cm}^{3}$ and a $189 \mathrm{~m}$ datum.

We used these gravity data along Line 2 together with additional gravity data provided by the Geological Survey of Sweden (SGU) in the study area to generate a Bouguer anomaly map (Fig. 5). The Bouguer anomaly map represents the differences in mass within the subsurface, which arise from variations in rock densities. It can be considered to be made up 
of a long wavelength regional field and a shorter wavelength residual field. The regional field is generally due to deeper structures, while the residual field generally represents shallow subsurface structures (El-Batroukh \& Zentani 1980; Li \& Oldenburg 1998; Nabighian et al. 2005; Xu et al. 2009; Cella \& Fedi 2012). In order to separate the residual field from the regional field we calculated the regional anomaly map by fitting a quadratic polynomial of 2 nd order to the data (Fig. 5). Then the residual anomaly map was obtained by subtracting the regional anomaly map from the Bouguer anomaly map (Fig. 5). We used the residual anomaly map as a basis for $2.5 \mathrm{D}$ forward modeling along the profile. A $2.5 \mathrm{D}$ model is a twodimensional model with the bodies restricted in their extension perpendicular to the profile. In our case the bodies extended $500 \mathrm{~m}$ on each side of the profile. A zero density contrast was used as background for the modeling.

\section{Results and interpretations}

In this section we present our interpretation of the four seismic profiles. As there is a considerable risk of over-interpreting these data, we have opted to present simplified interpretations, focusing on the features which we feel can be interpreted with the greatest confidence. It should be noted, however, that it is possible to interpret the data quite differently and still honor all available data.

A number of clear seismic reflections can be observed on the depth-converted seismic lines (Figs. 6, 7, 8, and 9). However, these reflections are typically not very continuous and cannot be clearly correlated across the seismic sections. The quality of the seismic image 
also varies along the seismic lines, which likely is due to changes in near surface conditions, environmental noise and the variable maximum offset between the source and receiver. Therefore, despite the availability of well data, the interpretation of the seismic data is still highly subjective.

Line 1 (Fig. 6) exhibits most reflections of all four seismic lines in this study. The reflections are discontinuous and are concentrated in the upper $350 \mathrm{~m}$ of the section. Towards NE, the reflections appear to predominantly dip to the SW, while in the center of the line and in SW the reflections are more horizontal or dipping to the NE. In places, these dipping reflections appear to be cut by linear discontinuities, some of which have been interpreted as fault planes. Lithological and lithostratigraphic data for the Mora MV-3 well are annotated on the seismic section (Fig. 6). The horizontal lines on the log indicate that a large portion of the rocks in the core is heavily faulted and consists of a package of impact-related thrust sheets (ranging in scale from millimeters to hundreds of meters). The location of the basement in the Mora MV-3 well corresponds to some very weak discontinuous events at the base of the section and the transition from a more reflective interval (sedimentary strata in this case) to a less reflective interval (basement in this case). Therefore, we have tentatively interpreted the basement across the section based on these weak events and on the transition from a reflective to a non-reflective sequence.

It is tempting to interpret the seismic events in the upper part of the section as an indication of bedding and to use them to trace the top of the Ordovician away from the well. This would suggest an Ordovician top dipping SW and hence a thinning sequence along the line. This is consistent with surface geology, where Ordovician strata outcrop NE of Line 1. However, it is perhaps more likely that the seismic reflections which are abundant in this part 
of the section instead are related to the lithological contrasts along the fault planes. In this case, the reflections would provide an image of the structure and geometry of the package of thrusted slices, instead of the original bedding planes within the sequence. It is clear that any correlation of the Ordovician across the section would be highly speculative and hence we do not present a preferred interpretation of this horizon here.

The depth-converted seismic section and interpretation of Line 2 is shown in Figure 7. To the NE of the line there is a package of relatively high amplitude and continuous reflections located between CDPs 120 and 200 at a depth of around $250 \mathrm{~m}$. Based on the data from the Mora 001 well, these reflections appear to correspond to the basement and top Ordovician interfaces, respectively. There appears to be a discontinuity marking the termination of this group of reflections at approximately CDP 250, which we have interpreted as a fault plane. As the sequence in the Mora 001 well appears to be relatively un-faulted, it is likely that this region of continuous seismic events represents a distinct, relatively undisturbed fault block. Hence, we suggest that the reflections around the Mora 001 well are representative of the original bedding of the sedimentary sequence. To the SW of the interpreted fault plane, the seismic appears to be relatively discontinuous with only two areas of high reflectivity at approximately CDP 260 and CDP 400 (at depths between 100 and 160 m). In the Mora 001 well, the basement can be correlated with some confidence up to the fault, where it appears to be sub-horizontal. To the SW of the fault, interpretation of the basement is more uncertain as no clear continuous events can be correlated to the basement in the Mora VM-2 well. In the absence of a strong reflection we have interpreted the basement to be approximately sub-horizontal to the SW of the section, paralleling the strong reflections in the shallower part of the profile. We interpret the $150 \mathrm{~m}$ difference in basement depth on this line to be due to the fault at CDP 250. It is clear, based on the geometry of the fault, that 
the basement has been subjected to normal displacement. However, some of the reflections in the shallower section to the SW of the fault plane appear to be curved, inferring some degree of compression. It should be noted that these apparent compressive features are clearer on Line 3 (Fig. 8), which also intersects this fault. We therefore interpret this to be a normal fault which has later been inverted. It is clear from the well information that the rocks are significantly more disturbed in the Mora VM-2 well than in the Mora 001 well. We therefore suggest that the large fault at CDP 250 on this line separates two distinct fault blocks with very different degrees of deformation. The higher degree of structural complexity could explain the difference in reflectivity between the SW and NE sides of the profile, as the relatively undeformed sequence close to the Mora 001 well would be expected to give a stronger and more continuous seismic response given the acquisition geometry of our survey.

Figure 8 shows the depth-converted seismic data and interpretation for Line 3. No well data are available on this line to help constrain the interpretation. Based on the intersection with Line 2, we suggest that the NW part of the profile is part of the relatively undeformed fault block which the Mora 001 well intersects. Hence, the relatively continuous package of reflections between CDP 100 and 250 at a depth of $250 \mathrm{~m}$ are thought to be associated with the Ordovician sequence. The major fault interpreted on Line 2 is also visible on this line at CDP 240, suggested by the termination of the reflections on either side of the fault plane. Based on the interpretation along Lines 2 and 3 this fault appears to strike $\mathrm{E}-\mathrm{W}$ and dip to the south. To be consistent with Line 2 we have interpreted the basement to be sub-horizontal across the profile and to have approximate depths of $400 \mathrm{~m}$ and $250 \mathrm{~m}$ on the SE and NW sides of the fault, respectively. As on Line 2, we observe normal displacement at the basement level, but indications of compression in the shallower reflections to the SE of the 
fault plane. However, on this line the curvature of the reflections is more prominent than on Line 2, with an anticline clearly observed SE of the main fault.

The depth-converted seismic for Line 4 is shown in Figure 9. This line exhibits the weakest seismic response of the four lines in the study area. Only one strong reflection in the center of the profile at approximately $100 \mathrm{~m}$ depth can be observed. The poor seismic response could be due to a combination of highly complex subsurface structure, sub-optimal seismic acquisition parameters and poor near surface conditions. Given the structural complexity indicated by the Mora VM-2 well and the lack of reflectivity on this line which do not warrant meaningful interpretation we only present un-interpreted data.

\section{Discussion}

Although the interpretations presented here for Lines 1, 2 and 3 are simplified, we are able to identify several distinct fault blocks with different degrees of structural complexity. These fault blocks and faults appear to be consistent between the seismic lines. Figure 10 shows the location of the major faults and fault blocks interpreted in this study with respect to surface geology and seismic profiles. We have interpreted three major fault blocks, separated by two E-W striking faults. The fault interpreted to exist between Lines 3 and 1 is not explicitly observed in the seismic data, but is inferred to be the boundary between the relatively undeformed sequence NW of Line 3 and the heavily deformed region along Line 1. An E-W strike may correspond to the ENE-WSW striking fault on the surface geology map located to the north of the survey area. It appears that the rocks of the southernmost block (intersected by the Mora VM-2 well) and northernmost block (intersected by the Mora MV-3 well) are 
heavily deformed. The rocks of the central block (intersected by the Mora 001 well) are interpreted to be relatively undeformed.

The quality of the seismic images obtained along the lines is variable, which gives rise to significant uncertainty in the interpretation of the data. Despite this, there are a number of features in the data which may be correlated with the available well data to make a set of interesting observations about the nature of the sedimentary strata in this area. Although the detrimental effects of environmental noise and near surface conditions are somewhat unavoidable when acquiring seismic data, it is likely that a better image could have been obtained along these lines if a longer receiver spread had been utilized.

The major fault interpreted on Lines 2 and 3 is one of the features in the seismic data which may be interpreted with a higher degree of confidence. The fault appears to initially have been normal but later inverted, implying a period of extension followed by compression. This could be explained by a period of extension during the impact modification stage, when material began to move towards the center of the impact as the transient crater collapsed. Compression could then have occurred at the very end of the modification stage, when the material sliding towards the crater center came to an abrupt stop.

As well as degree of deformation, the type of lithology encountered appears to vary significantly between fault blocks. For example, in the Mora VM-2 well, mound facies which are observed in neither the Mora MV-3 nor Mora 001 wells. The Ordovician strata in the Mora MV-3 well appear to be predominantly shales, whereas those in the Mora 001 well are predominantly limestone. This implies that strata in the different fault blocks were transported some distance during the impact process, leading to juxtaposition of rocks originating from different pre-impact locations. The allochtonous Boda mound facies are typically only 
observed in the central, eastern, northeastern and northern parts of the Siljan Ring (Fig. 1). This implies that they were transported great distances during the impact. This may have occurred if they were ejected into the air from somewhere close to the center of the ring and subsequently landed in the study area. Alternatively, these mound facies, which may be considered as lenses of relatively hard and competent limestone, were forced great distances through more plastic shale sequences.

The density measurements from the Mora VM-2 core samples (Table 3) and the lithology of the wells Mora 001, Vattumyra Production and Mora VM-2 were used to construct a forward model of the subsurface geology. Additionally, we used the interpretation outlined in the depth-converted seismic section along Line 2 (Fig. 7). Figure 11 shows the density model along Line 2, with the gravity anomaly increasing from southwest to northeast. The best fit between the density model response and the measured data was obtained using the layer density contrasts $-0.04 \mathrm{~g} / \mathrm{cm}^{3}$ and $0.085 \mathrm{~g} / \mathrm{cm}^{3}$ for Paleozoic and basement rocks, respectively. The general trend in the gravity anomaly is re-created by the model, while the shorter wavelength anomalies are not matched. It is possible to fit these short wavelength anomalies by introducing a thin near surface layer of variable thickness with a high negative density contrast (Muhamad 2017). Such a layer would correspond to the recent glacial deposits. The density model along this profile shows significant changes in subsurface geology, both horizontally and vertically (Fig. 11). Furthermore, the thicknesses of the Paleozoic rocks are thickest in the southwestern and thinnest in the northeastern part. This density model is consistent with the seismic interpretation.

\section{Conclusions}


Petrophysical measurements on core from the Mora VM-2 well provided a basis to generate a synthetic seismogram to tie with the seismic sections. Despite significant uncertainty in the seismic interpretation, ground gravity data combined with well data provide valuable information to help gain insight into the complex nature of the subsurface in this area. We have identified 3 different fault blocks in the area. The rocks in two of these fault blocks, intersected by the Mora VM-2 and Mora MV-3 wells appear to be highly deformed while those in a block intersected by the Mora 001 well appear to be relatively undisturbed. A major fault intersects both Lines 2 and 3 and appears to initially have been normal but later inverted. The density model shows that the crystalline rocks are denser than the Paleozoic ones along Line 2 . The basement rocks have the highest density contrast (about $0.085 \mathrm{~g} / \mathrm{cm}^{3}$ ) relative to the background density.

The seismic results as well as the core log studies demonstrate that the larger fault blocks within the impact structure have been affected differently by the impact-related tectonics, presumably due to different lithological competences of the sedimentary facies in areas with deeper water depositional environments to the west and a carbonate shelf with late Ordovician reef mound systems to the east. There are highly deformed domains present in areas of the shale- and mudstone-dominated western Siljan Ring structure (thrusted fault blocks and zones), possibly caused by injections of rigid blocks originating from the original impact site to the east. This is exemplified by the partly subvertical block of Boda Limestone detected in Mora VM-2 well that probably was thrusted upon an autochthonous Lower to Upper Ordovician limestone succession. Overturned and recumbent folding and internal thrusting is observed in the Mora MV-3 well, which gives rise to multiple repetitions of mainly Silurian and Upper Ordovician formations. 


\section{Acknowledgements}

We thank Igrene $A B$ for partly funding the field work and providing logistical support during the acquisition. The authors would like to thank the Geological Survey of Sweden (SGU) for providing the gravity data. Seismic data processing was carried out using GLOBE Claritas ${ }^{\text {TM }}$ under license from the Institute of Geological and Nuclear Sciences Limited, Lower Hutt, New Zealand and gravity data modeling using Model Vision $\mathrm{Pro}^{\mathrm{TM}}$. H. Muhamad would like to thank the Salahaddin University and Ministry of Higher Education and Scientific Research of Kurdistan Region for their support and funding to study abroad. OL contributed during his stay at the Czech University of Life Sciences in Prague supported by the Alexander von Humboldt Foundation (Germany) and at Nanjing Institute of Geology and Palaeontology (NIGPAS, China) as a visiting professor. He is grateful for the support of his research in the Siljan impact structure by the Deutsche Forschungsgemeinschaft (DFG project LE 867/8-1 and 8-2). We also thank two anonymous reviewers and the editor who provided very constructive and conscientious reviews.

\section{References}

Arslan, A., Meinhold, G. \& Lehnert, O., 2013: Ordovician sediments sandwiched between Proterozoic basement slivers: tectonic structures in the Stumsnäs 1 drill core from the Siljan Ring, central Sweden. GFF 135, 213-227.

Boden, A. \& Eriksson, K.G., 1988: Deep Drilling in Crystalline Bedrock. Vol. 1: The Deep Gas Drilling in the Siljan Impact Structure, Sweden and Astroblemes, Proceedings of the International Symposium. Springer Verlag, Berlin. 364 pp.

Brodic, B., Malehmir, A., Juhlin, C., Dynesius, L., Bastani, M. \& Palm, H., 2015: Multicomponent broadband digital-based seismic land streamer for near-surface applications. Journal of Applied Geophysics 123, 227-241.

Cella, F. \& Fedi, M., 2012: Inversion of potential field data using the structural index as weighting function rate decay. Geophysical Prospecting 60(2), 313-336.

Collini, B., 1988: Geological Setting of the Siljan Ring Structure Deep Drilling in Crystalline Bedrock. In A. Boden \& K.G. Eriksson (eds.): Deep drilling in crystalline bedrock, 349- 
354. Vol. 1. The Deep Gas Drilling in the Siljan Impact Structure, Sweden and Astroblemes, Proceedings of the International Symposium. Springer Verlag, Berlin.

Donofrio, R.R., Olsen, K.H., Vlierboom, F.W., Witschard, F. \& Petersson, G., 1984: Deep Gas, Swedish premises: the Siljan Ring project: independent expert evaluation. Stockholm, Vattenfall. $63 \mathrm{pp}$.

El-Batroukh, S.I. \& Zentani, A.S., 1980: Gravity interpretation of Raguba field, Sirte basin, Libya. Geophysics 45(7), 1153-1163.

Ebbestad, J.O.R. \& Högström, A.E.S., 2007: Ordovician of the Siljan district, Sweden. In J.O.R. Ebbestad, L.M. Wickström, \& A.E.S. Högström (eds.): WOGOGOB 2007. 9th meeting of the Working Group on Ordovician Geology of Baltoscandia. Field guide and Abstracts. Sveriges geologiska undersökning Rapporter och meddelanden 128, 7-26.

Jourdan, F., Reimold, W.U. \& Deutsch, A., 2012: Dating terrestrial impact structures, Elements 8, 49-53.

Juhlin, C., \& Pedersen, L.B., 1987: Reflection seismic investigations of the Siljan impact structure, Sweden. Journal of Geophysical Research 92, 14113-14122.

Juhlin, C., 1990: Interpretation of the reflections in the Siljan Ring area based on results from the Grayberg-1 borehole. Tectonophysics 173, 345-360.

Juhlin, C., Sturkell, E., Ebbestad, J.O.R., Lehnert, O., Högström, A.E.S. \& Meinhold, G., 2012: A new interpretation of the sedimentary cover in the western Siljan Ring area, central Sweden, based on seismic data. Tectonophysics 580, 88-99.

Kresten, P., Aaro, S., \& Karis, L., 1992: Latest results of bedrock mapping in the Siljan area, In D. G. Gee (Ed.), Geologiska Föreningens i Stockholm Förhandlingar 114, 155-164.

Lehnert, O., Meinhold, G., Bergström, S.M., Calner, M., Ebbestad, J.O.R., Egenhoff, S., Frisk, A.M., Hannah, J.L., Högström, A.E.S., Huff, W.D., Juhlin, C., Maletz, J., Stein, H.J., Sturkell, E. \& Vandenbroucke, T.R.A., 2012: New Ordovician-Silurian drill cores from the Siljan impact structure in central Sweden: an integral part of the Swedish Deep Drilling Program. GFF 134, 87-98. 
Lehnert, O., Meinhold, G., Arslan, A., Ebbestad, J.O.R. \& Calner, M., 2013: Ordovician stratigraphy of the Stumsnäs 1 drill core from the southern part of the Siljan Ring, central Sweden. GFF 135, 204-212.

Li, Y. \& Oldenburg, D.W., 1998: Separation of regional and residual magnetic field data. Geophysics 63, 431-439.

Muhamad, H., Juhlin, C., Lehnert, O., Meinhold, G., Andersson, M., Garcia Juanatey, M. \& Malehmir, A., 2015: Analysis of borehole geophysical data from the Mora area of the Siljan Ring impact structure, central Sweden. Journal of Applied Geophysics 115, 183196.

Muhamad, H., 2017: Geophysical studies in the western part of the Siljan Ring Impact Crater. Digital Comprehensive Summaries of Uppsala Dissertations from the Faculty of Science and Technology 1468. 69 pp. Uppsala: Acta Universitatis Upsaliensis. ISBN 978-91-554-9794-1.

Nabighian, M.N., Ander, M.E., Grauch, V.J.S., Hansen, R.O., LaFehr, T.R., Li, Y., Pearson, W.C., Peirce, J.W., Phillips, J.D. \& Ruder, M.E., 2005: Historical development of the gravity method in exploration. Geophysics 70, 63-89.

Papasikas, N. \& Juhlin, C., 1997: Interpretation of reflections from the central part of the Siljan Ring impact structure based on results from the Stenberg-1 borehole. Tectonophysics 269, 237-245.

Xu, Y., Hao, T., Li, Z., Duan, Q. \& Zhang, L., 2009: Regional gravity anomaly separation using wavelet transform and spectrum analysis. Geophysics and Engineering 6(3), 279-287. 


\section{Table captions}

Table 1. Data acquisition parameters

Table 2. Processing steps and parameters

Table 3. Petrophysical data measurements on core samples from the Mora VM-2 well.

\section{Figure captions}

Fig. 1. Geological map of the Siljan Ring area with location of the Igrene AB drill core sites and the location of seismic profiles marked. Study area is shown by the red rectangle southwest of the town of Mora (modified from Ebbestad \& Högström 2007). 
Fig. 2. Base map of the study area showing locations of the wells (black circles) and ground gravity points (hollow circles). The CDP positions for the four lines are shown as black lines, CDP numbers are indicated at regular intervals. The gray dots indicate the trace mid-points for the seismic data.

Fig. 3. A summary of the well data from the Igrene $A B$ wells (see Fig. 2 for well locations). Where available, natural gamma ray (black curve) and p-wave sonic (red curve) are displayed. The interpreted lithology and lithostratigraphy within the wells is also shown. For illustrative purposes, an approximate, blocked natural gamma ray log is shown for parts of the well where no data were recorded (black dashed line).

Fig. 4. Synthetic seismogram generated from the pseudo blocked sonic and density logs in the Mora VM-2 well.

Fig. 5. A. Gravity anomaly map. B. Regional gravity anomaly map. C. Residual gravity anomaly map of the study area. Plus (+) symbols represent the gravity ground stations. The black lines show the locations of CDPs seismic lines.

Fig. 6. The upper image shows the final processed seismic depth section for Line 1. Both core lithology (left hand side) and lithostratigraphy (right hand side) are annotated for the Mora MV-3 well. The seismic interpretation, denoting the thickness of the Paleozoic sequence and the location of faults is shown in the lower image.

Fig. 7. The upper image shows the final processed seismic depth section for Line 2. Both core lithology (left hand side) and lithostratigraphy (right hand side) are annotated for the Mora 001 
and Mora VM-2 wells. The seismic interpretation, denoting the thickness of the Paleozoic sequence and the location of faults is shown in the lower image.

Fig. 8. The upper image shows the final processed seismic depth section for Line 3. The seismic interpretation, denoting the thickness of the Paleozoic sequence and the location of faults is shown in the lower image.

Fig. 9. The final processed seismic depth section for Line 4. Both core lithology (left hand side) and lithostratigraphy (right hand side) are annotated for the Mora VM-2 well.

Fig. 10. A. Map showing the location of the major faults and fault blocks. The location of the schematic section shown in B (profile A - A') is annotated as a dotted line. B. A schematic section describing an approximately NE-SW profile through the study area. The 3 fault blocks described on the map in A are annotated. The thin black lines annotated in the Paleozoic succession within Fault blocks 1 and 3 show the approximate geometry of reflections within the seismic data (observed along lines 1, 2 and 3). The thin black lines annotated in the Paleozoic succession in Fault block 2 show the interpreted lithology within the fault block. Here we assume that the sequence encountered in the Mora 001 well extends across the entire fault block.

Fig. 11. Gravity modeling along seismic Line 2, based on the interpretation of the seismic reflection data, density core samples and lithologies of the wells. A. Gravity model. B. Integration of the seismic section and model based on the interpretation of the gravity data. The numbers in B represents the density contrast. 
Figure 01 (top)

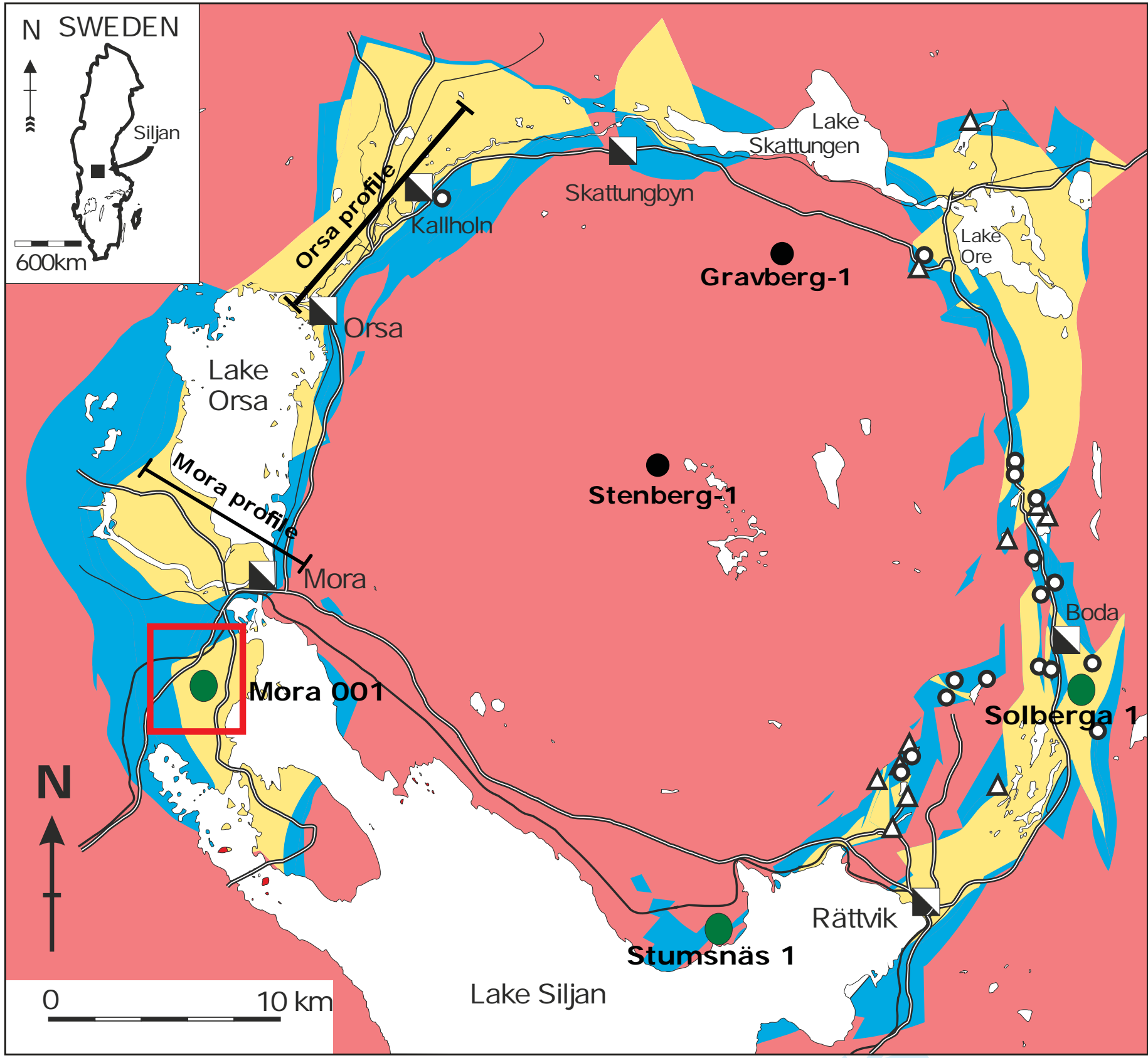

\section{Legend}

Town/community

Precambrian bedrock

Late Tremadocian to

Wenlock sedimentary rock Late Silurian sedimentary rock (Orsa Sandstone) $\triangle$ Kullsberg Mounds

- Boda Mounds

$\Longleftarrow$ Roads Rail road Igrene $\mathrm{AB}$ drill sites
Deep well

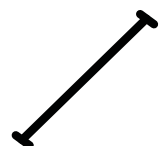

Seismic profiles

Study area 


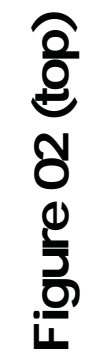

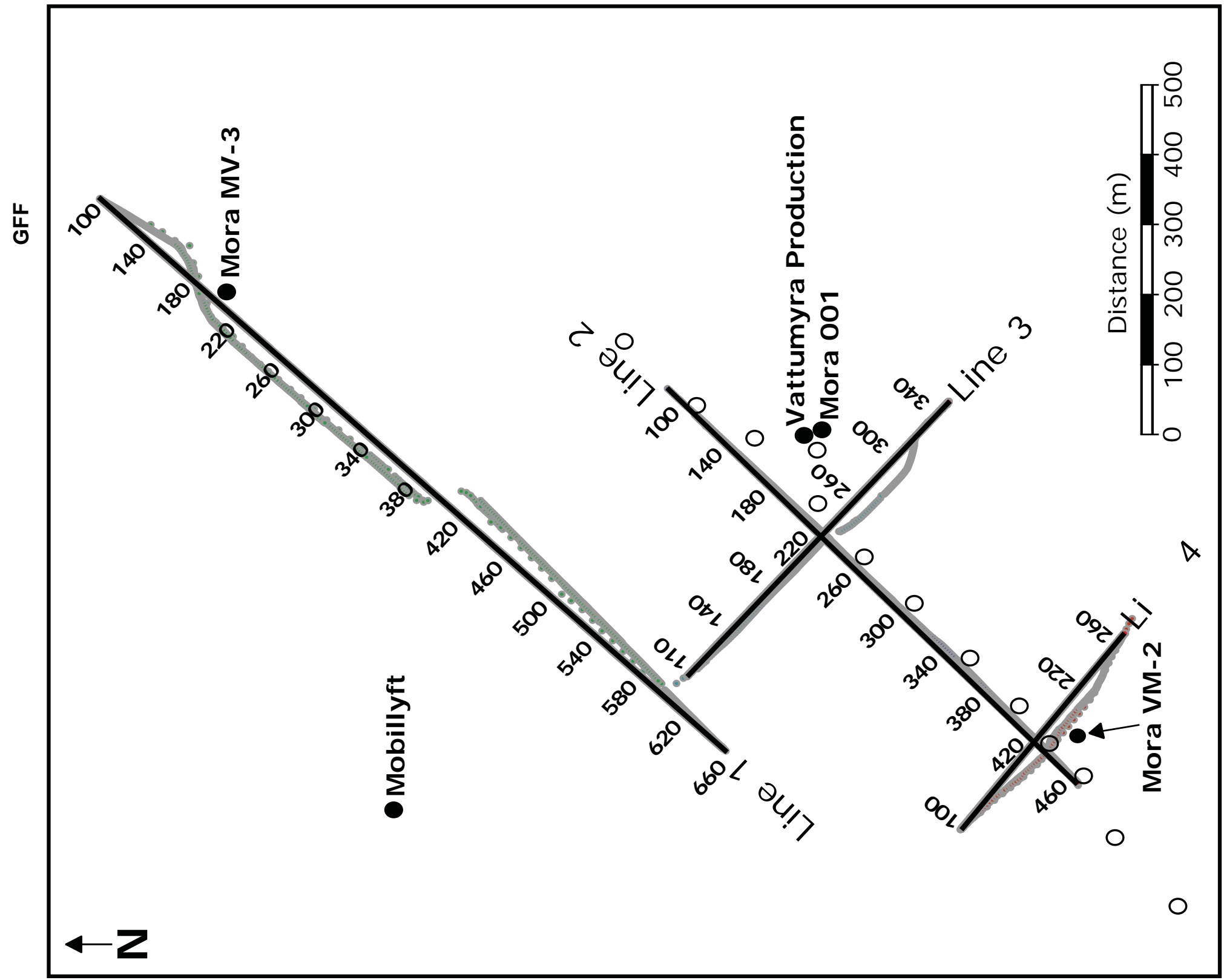




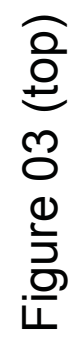
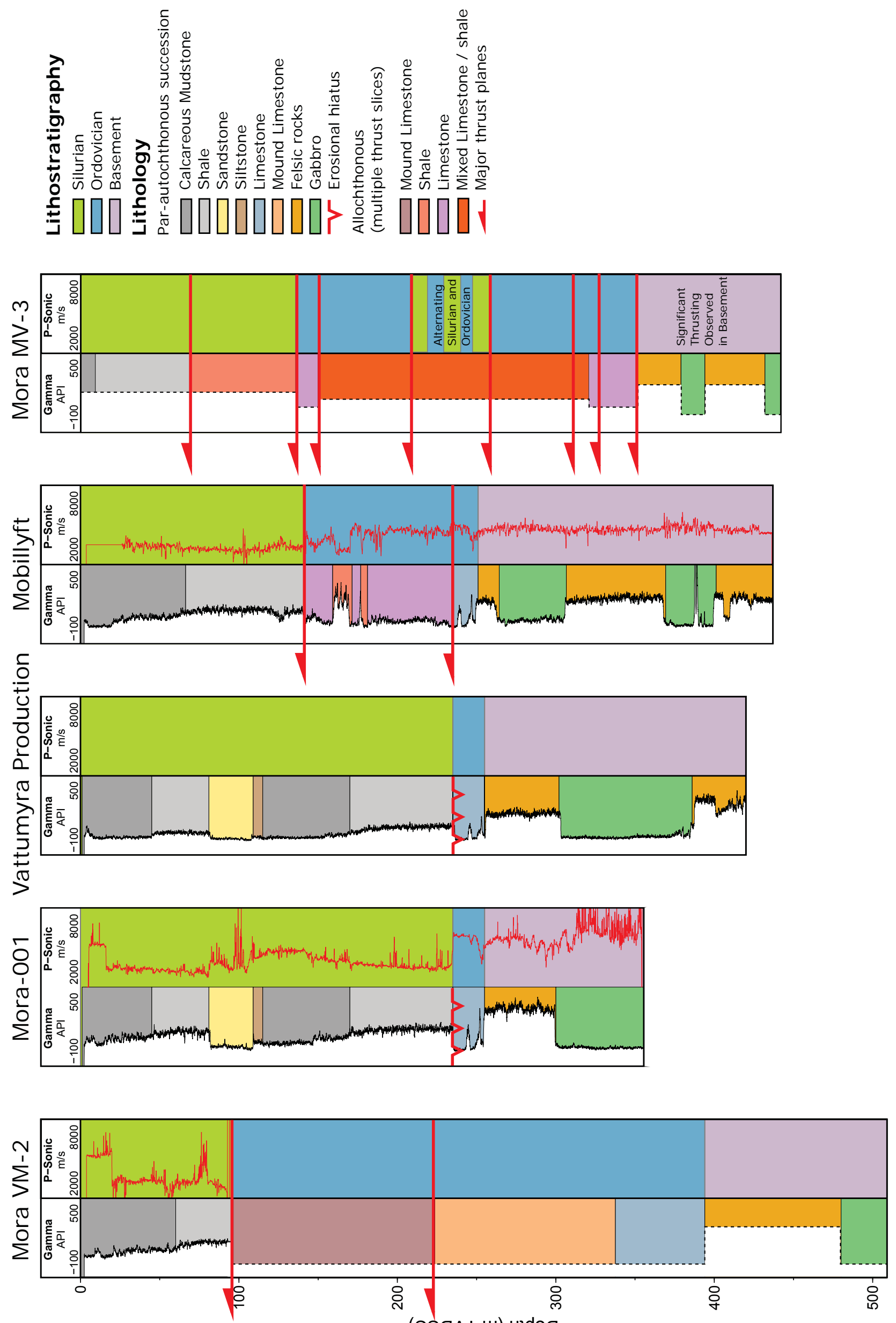

- N m 


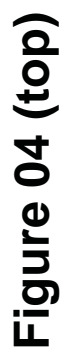
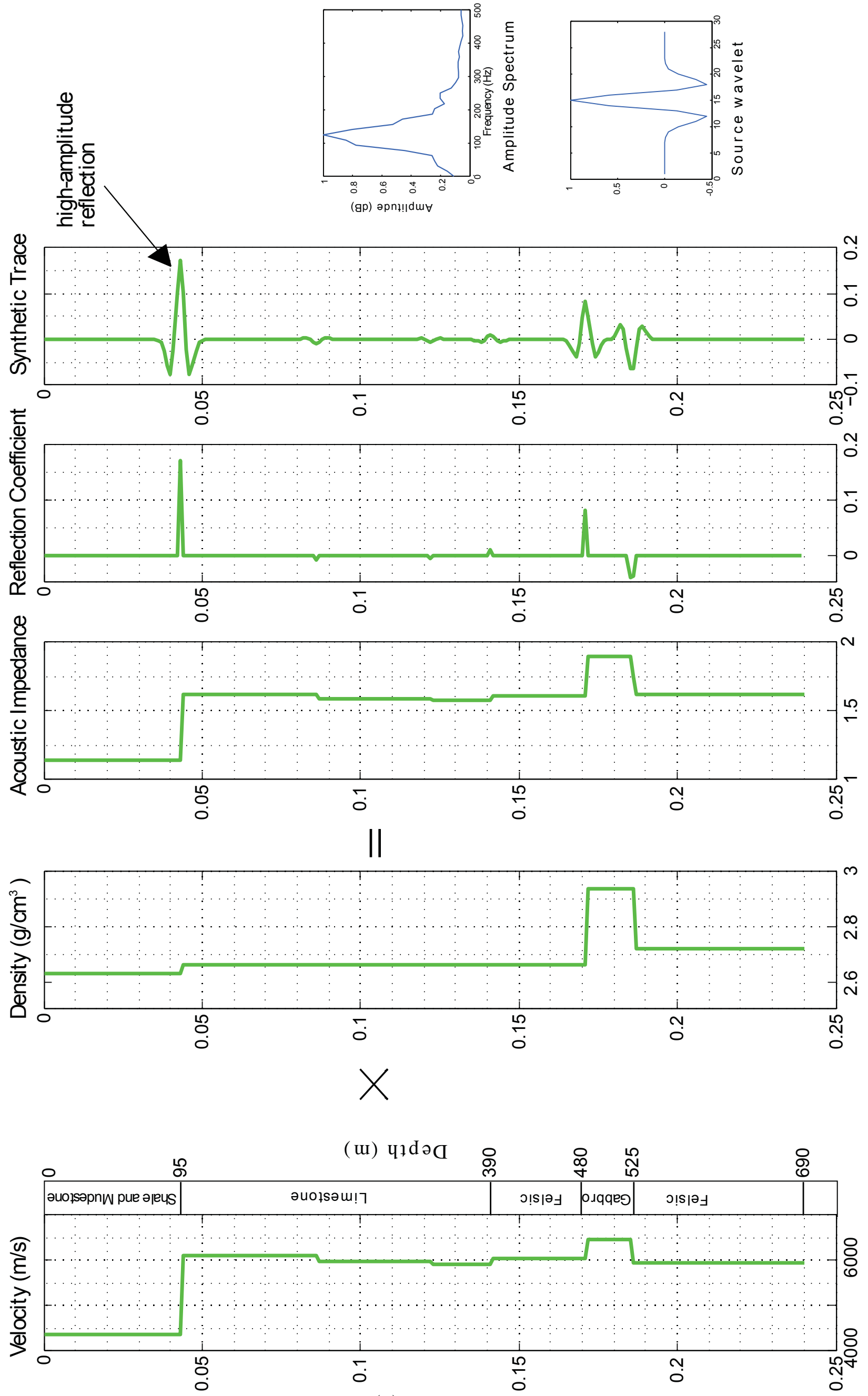

(s) LML

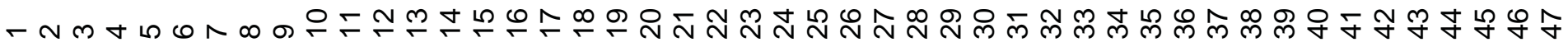



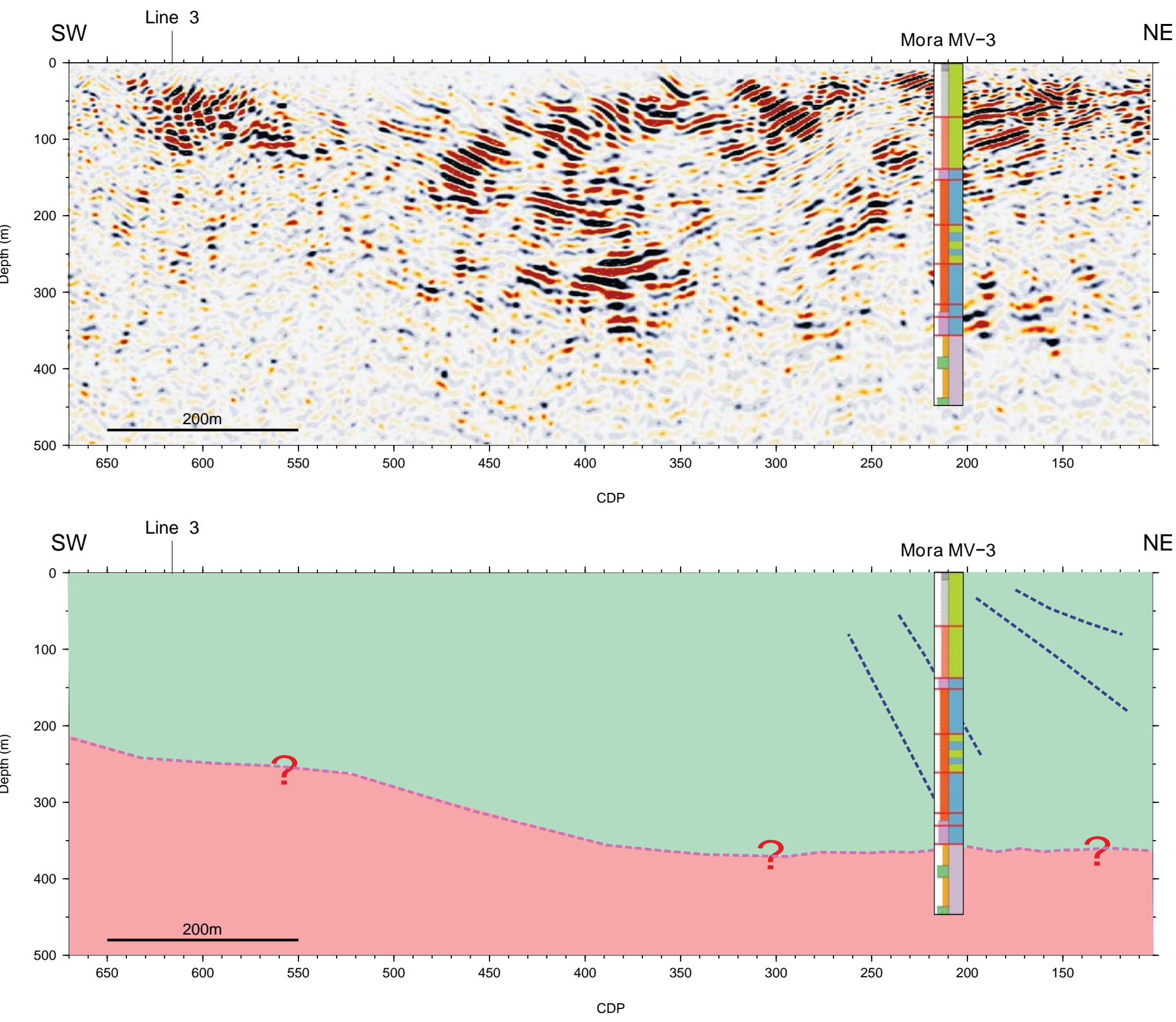

Well lithology (left)

Par-autochthonous succession

$\square$ Calcareous Mudstone
Shale
$\square$ Sandstone
Siltstone
$\square$ Limestone
$\square$ Mound Limestone
$\square$ Felsic rocks
Gabbro
$\square$ Erosional hiatus

Well lithostratigraphy (right)

Allochthonous

(multiple thrust slices)

$\square$ Mound Limestone Shale

Limestone

Mixed Limestone / shale

Thrust plane $\square$ Silurian

Ordovician

Basement

\section{Seismic interpretation}

$\square$ Paleozoic rocks

Crystalline rocks

-........ Fault

-... Boundary 

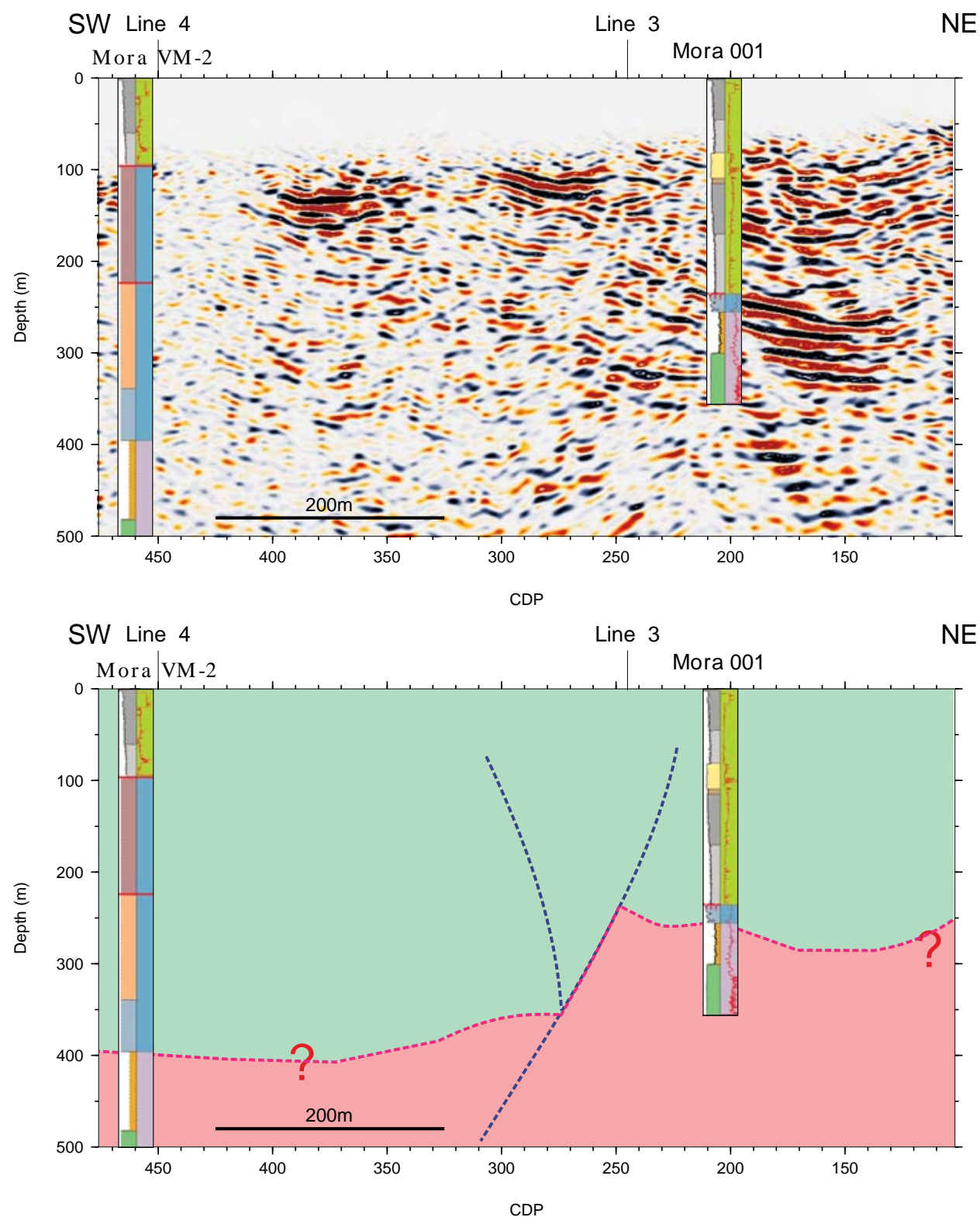

\section{Well lithology (left)}

Par-autochthonous succession

$\square$ Calcareous Mudstone Shale

Sandstone

Siltstone

Limestone

Mound Limestone

Felsic rocks

Gabbro

$\sqrt{ }$ Erosional hiatus

Well lithostratigraphy (right)

Allochthonous

(multiple thrust slices)

$\square$ Mound Limestone

$\square$ Shale

$\square$ Limestone

$\square$ Mixed Limestone / shale Thrust plane
Well lithostrat
$\square$ Silurian

$\square$ Ordovician

$\square$ Basement

Seismic interpretation

$\square$ Paleozoic rocks

Crystalline rocks

……. Fault

$+\cdots$ Boundary

NE

NE 

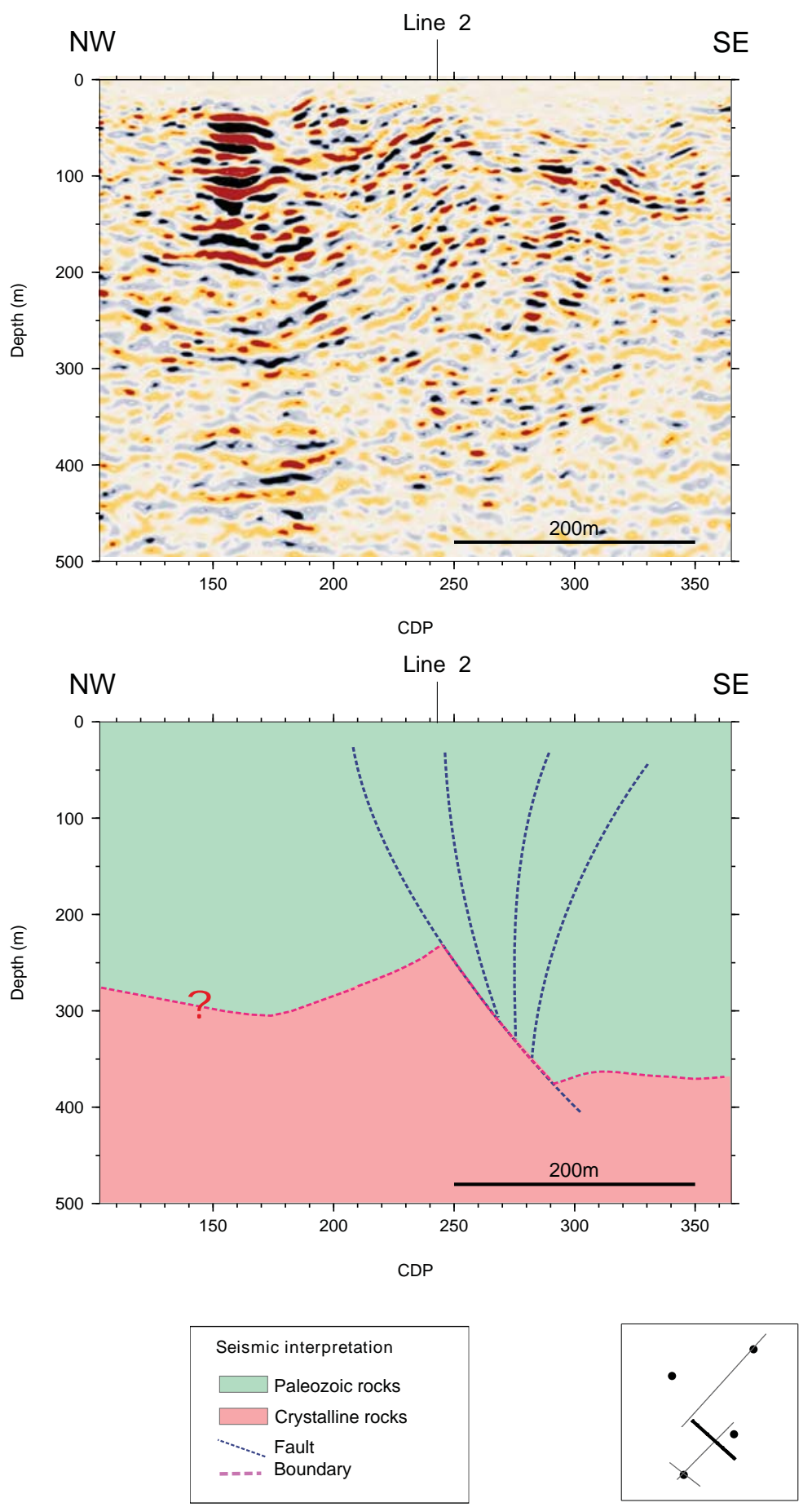


\section{Well lithology (left)}

Par-autochthonous succession Calcareous Mudstone Shale Sandstone Siltstone Limestone Mound Limestone Felsic rocks Gabbro

7 Erosional hiatus

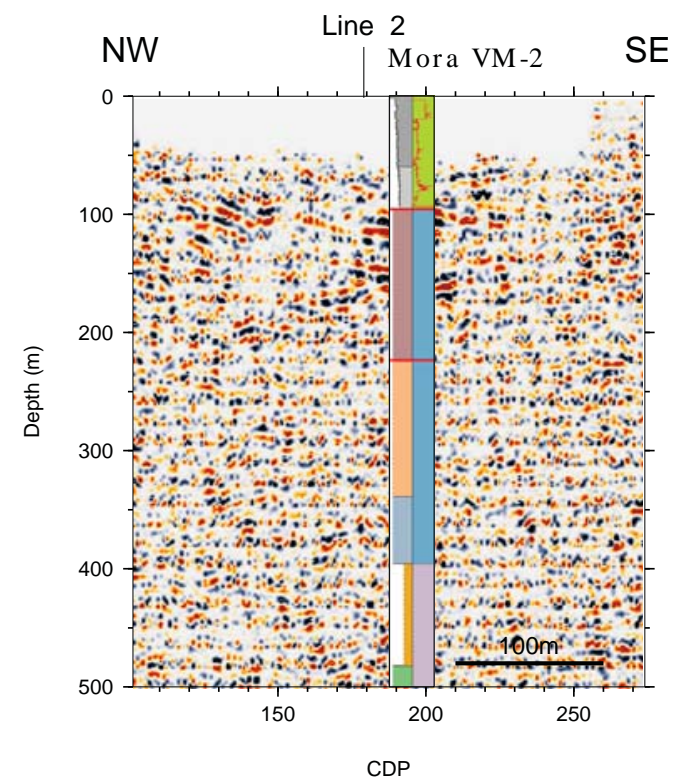

Allochthonous

(multiple thrust slices)

$\square$ Mound Limestone

Shale

Limestone

$\square$ Mixed Limestone / shale

Thrust plane
Well lithostratigraphy (right)

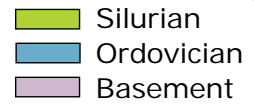

\section{Seismic interpretation}

$\square$ Paleozoic rocks

Crystalline rocks

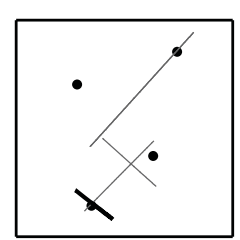


Figure 10 (top)

A

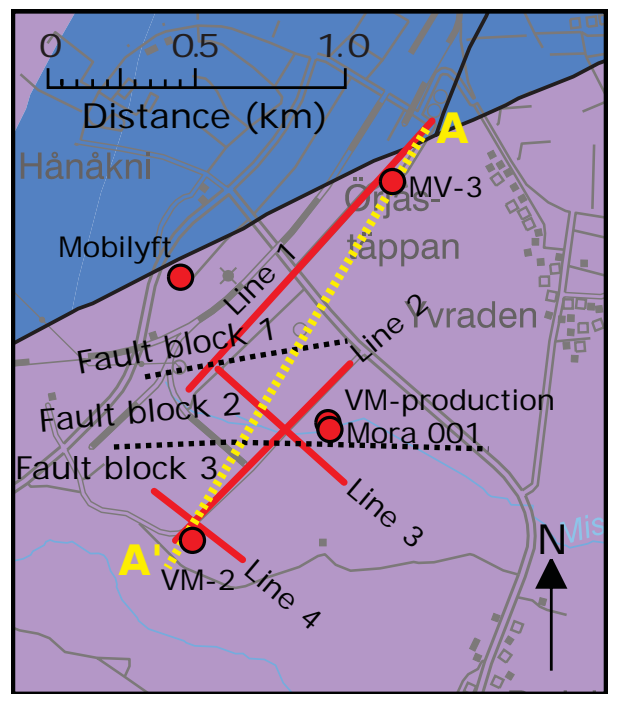

B

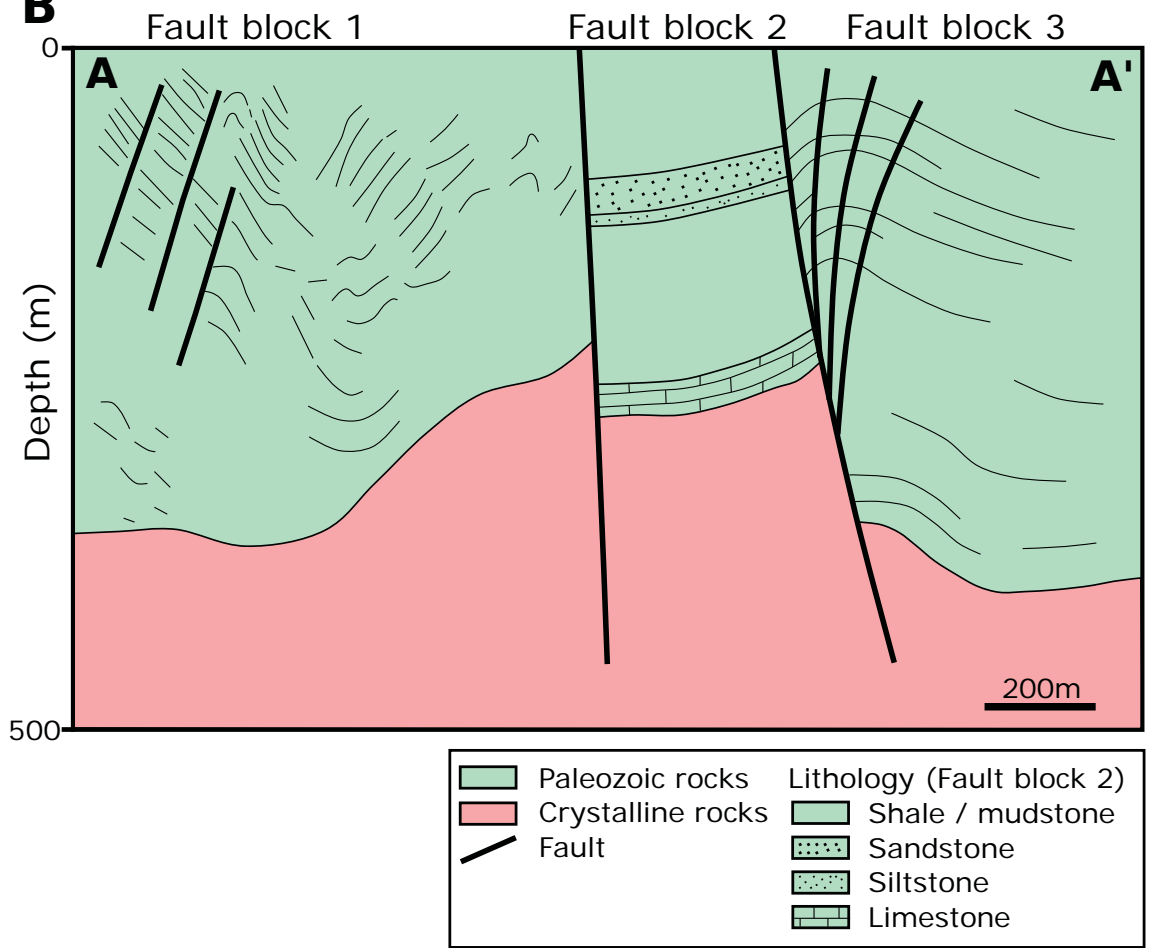




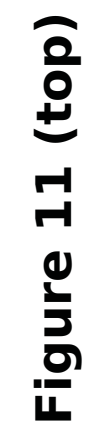
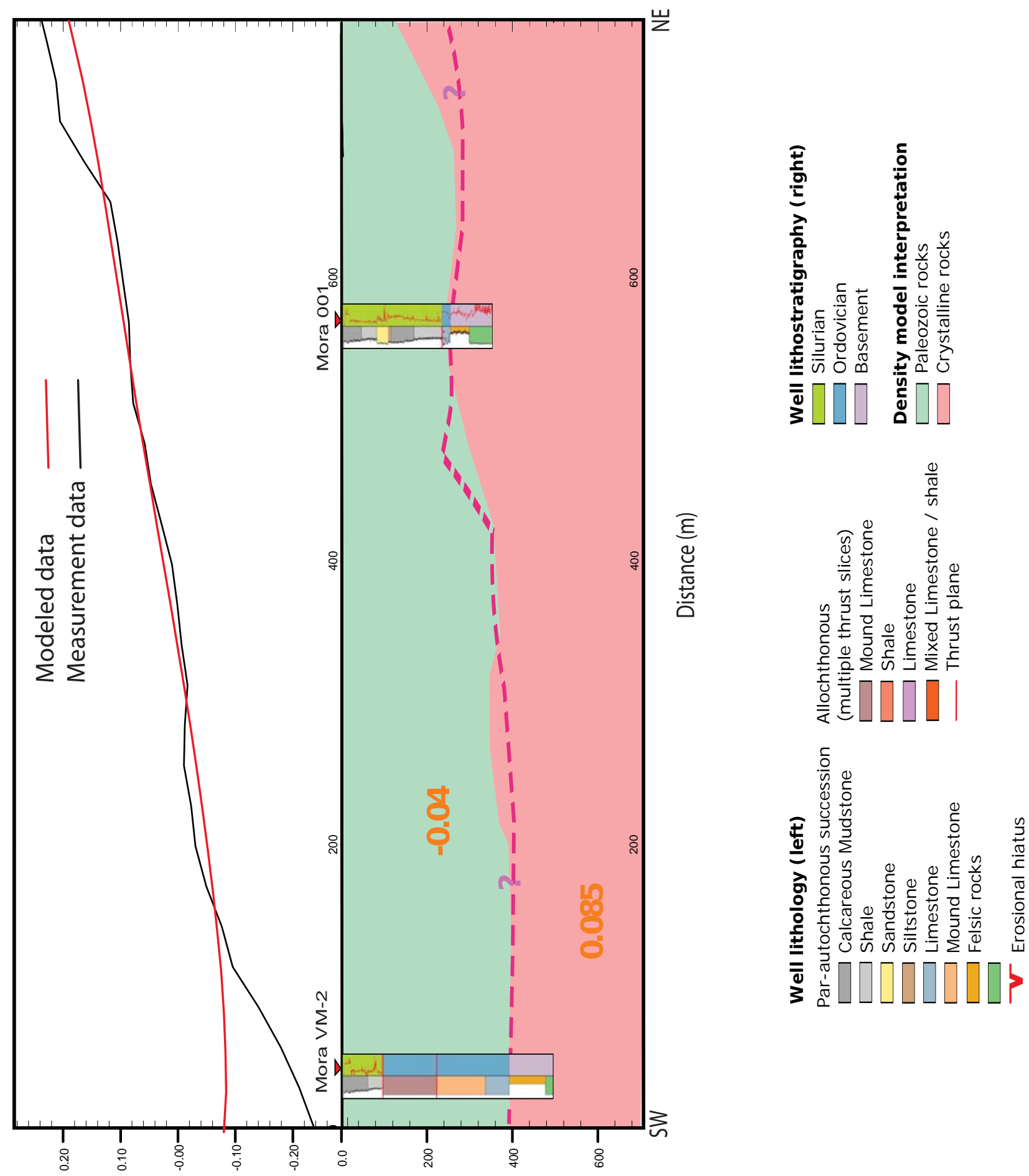

(ןеgu)

(iu) प1dəO

jenp!səy

$\varangle$ 


\begin{tabular}{|c|c|c|c|c|}
\hline Parameters & Line 1 & Line 2 & Line 3 & Line 4 \\
\hline Recording system & SERCEL 428 & SERCEL 428 & SERCEL 428 & SERCEL 428 \\
\hline Source type & Bobcat drop hammer & Bobcat drop hammer & Bobcat drop hammer & Bobcat drop hammer \\
\hline Sweeps & 5 hits & 5 hits & 5 hits & 5 hits \\
\hline Sample rate(ms) & 1 & 1 & 1 & 1 \\
\hline Recording length (s) & 25 (1used) & 25 (1used) & 25 (1used) & 25 (1used) \\
\hline Sensors & $\begin{array}{c}\text { DSU3, Streamer, 1C } \\
\text { Wireless }\end{array}$ & $\begin{array}{c}\text { DSU3, Streamer, 1C } \\
\text { Wireless }\end{array}$ & $\begin{array}{c}\text { DSU3, Streamer, 1C } \\
\text { Wireless }\end{array}$ & $\begin{array}{c}\text { DSU3, Streamer, 1C } \\
\text { Wireless }\end{array}$ \\
\hline Receiver spacing (m) & $\begin{array}{l}\text { 2-4 (streamer), 4-20 } \\
\text { (wireless) }\end{array}$ & $\begin{array}{c}\text { 2-4 (streamer), 4-20 } \\
\text { (wireless) }\end{array}$ & $\begin{array}{c}\text { 2-4 (streamer), 4-12 } \\
\text { (wireless) }\end{array}$ & $\begin{array}{c}\text { 2-4 (streamer), } 12 \\
\text { (wireless) }\end{array}$ \\
\hline Shot spacing (m) & 4 & 4 & 4 & 4 \\
\hline Number of receivers & $\begin{array}{c}80 \text { land streamer, } 47- \\
1 \mathrm{C} \text { wireless }\end{array}$ & $\begin{array}{l}80 \text { land streamer, } \\
47-1 \mathrm{C} \text { wireless }\end{array}$ & $\begin{array}{l}80 \text { land streamer, } \\
50-1 \mathrm{C} \text { wireless }\end{array}$ & $\begin{array}{c}80 \text { land streamer, 33- } \\
\text { 1C wireless }\end{array}$ \\
\hline Number of shots & 388 & 185 & 152 & 92 \\
\hline Profile length (m) & 1150 & 790 & 540 & 350 \\
\hline
\end{tabular}




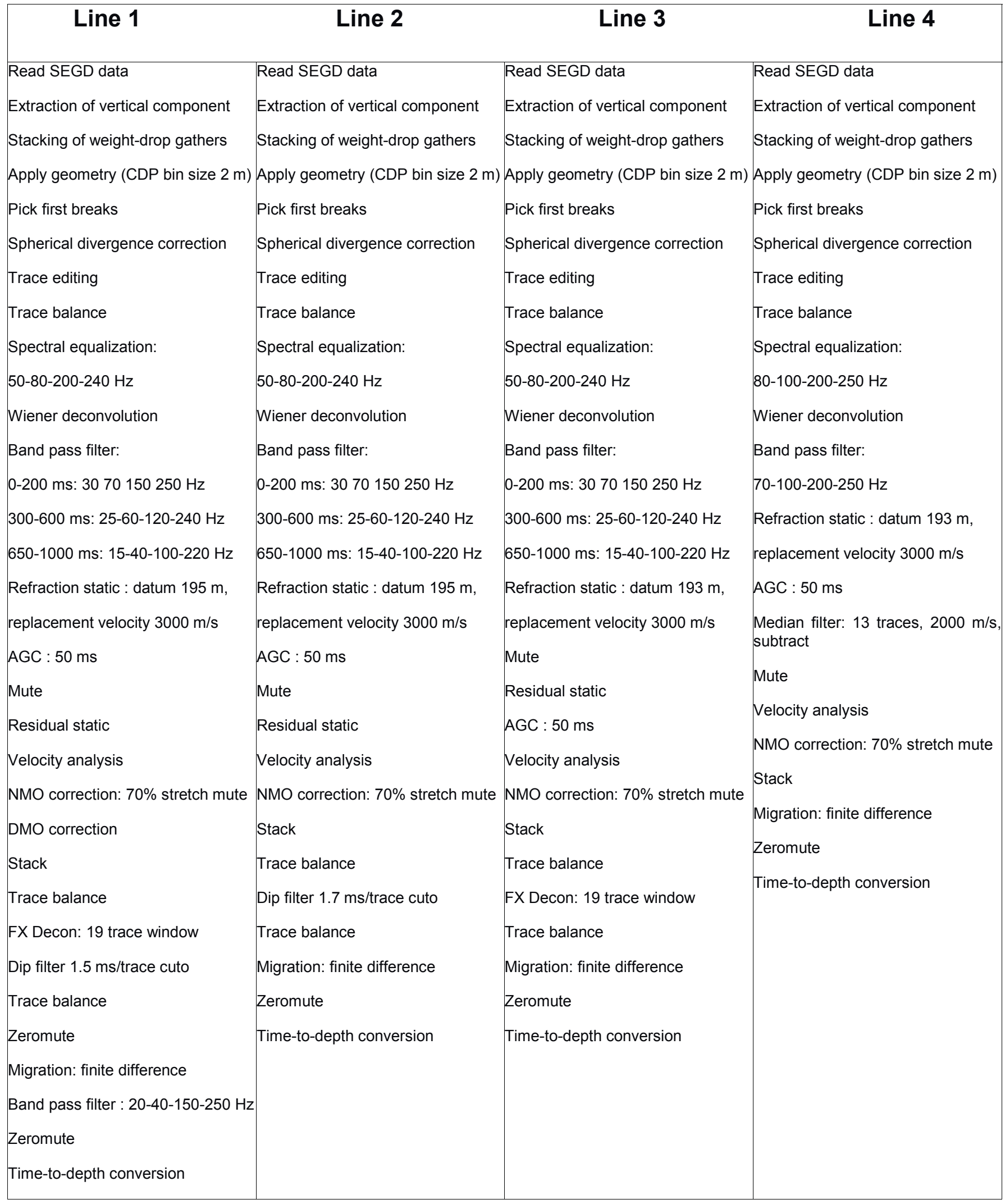




\begin{tabular}{|l|c|c|c|c|}
\hline \multicolumn{1}{|c|}{ Lithology } & Depth $(\mathrm{m})$ & $\begin{array}{c}\text { No. of } \\
\text { samples }\end{array}$ & $\begin{array}{c}\text { Average p-wave } \\
\text { velocity }(\mathrm{m} / \mathrm{s})\end{array}$ & $\begin{array}{c}\text { Average density } \\
\left(\mathrm{g} / \mathrm{cm}^{3}\right)\end{array}$ \\
\hline $\begin{array}{l}\text { Shale and } \\
\text { Mudstone }\end{array}$ & $0-95$ & 6 & 4361 & 2.63 \\
\hline Limestone & $95-225$ & 7 & 6104 & 2.64 \\
\hline Limestone & $225-335$ & 9 & 5990 & 2.67 \\
\hline Limestone & $335-390$ & 6 & 5930 & 2.69 \\
\hline Felsic rocks & $390-480$ & 4 & 6045 & 2.94 \\
\hline Mafic rocks & $480-525$ & 4 & 6455 & 2.69 \\
\hline Felsic rocks & $525-690$ & 6 & 5953 & \\
\hline
\end{tabular}

